\title{
Mekanisme Islamic Corporate Governance Pada Kinerja Bank Umum Syariah Menggunakan Islamic Performance Index
}

\author{
Oktaviani Rita Puspasari \\ (Oktavianipuspasari@gmail.com)
}

Universitas Kuningan

\begin{abstract}
This study examine how Islamic Corporate Governance mechanism which are : a number of sharia supervisory board meeting, independent directors, a number of audit committee meeting has an effect to the Islamic Bank performance in Indonesia which meassured by Islamic Performance Index, which proxy by : Profit sharing ratio (PSR), Islamic Income Ratio (IIR) and Equitable Distribution Ratio (EDR). The sample selection method is purposive sampling and obtained 9 Islamic bank in 5 years period observation with 45 data are being sampled. Multiple regression analysis is used to analyze the data. The results shows that a number of DPS meeting have a negative effect to PSR\&EDR, however positive effect showed for IIR. Then, independent directors have a negative effect to the PSR and IIR, however it has positive effect for EDR. As well as, negative effect showed by a number of audit committee meeting to PSR and IIR, while a number of audit committee meeting have positive effect for EDR. However the analysis result show that there are no significant effect from independent variable to the Islamic Bank performance which measured by Islamic Performance Index.
\end{abstract}

Keyword: A number of Sharia Supervisory Board meetings, Independent Directors, a number of audit committee meeting, Islamic Bank Performance.

\section{Pendahuluan}

Perkembangan perbankan syariah merupakan bagian dari perekonomian Islam, dimana sistem keuangan Islam telah berkembang mulai abad pertengahan. Namun dalam beberapa dekade terakhir, terlihat perkembangan ekonomi global terlihat tidak signifikan. Ekonomi Islam sendiri mulai bangkit dan menunjukan kinerjanya disebabkan dengan adanya kebutuhan religiousity dari populasi Muslim dunia yang menginginkan untuk mengembangkan produk dan jasa keuangan yang sesuai dengan keyakinan agama mereka, selain itu juga peningkatan pendapatan sumber daya minyak dari berbagai Negara Muslim Arab selama 1970an (M Larshb, 2015). Ditambah lagi, ketidakpuasan beberapa Muslim terhadap ideologi materialisme kapitalisme dan komunisme pada kinerja pasar keuangan barat yang tidak merata (Grais dan Pellegrini, 2006 pada M Larshb, 2015). Populasi 
Muslim menginginkan aturan aktivitas bisnis dan perekonomian adalah sejalan dengan aturan Islam yaitu mengedepankan kejujuran dan transaksi yang adil, sehingga pelaku bisnis Muslim harus memiliki nilai moral, dan pasar harus bebas.

Penilaian terhadap kinerja lembaga keuangan syariah sama pentingnya dengan mengukur pencapaian dari aktivitas invidual. Hal ini sesuai dengan peran dan tanggung jawab dari lembaga keuangan syariah yang tidak hanya dibatasi pada pencapaian kebutuhan informasi keuangan dari para stakeholder, namun juga terhadap aktivitas yang dilakukan oleh institusi dalam hal ini tentang konsistensinya dalam menerapkan prinsip-prinsip syariah. Oleh sebab itu, kepercayaan publik dalam hal ini sebagai shareholder pada khususnya maupun stakeholder pada umumnya ditentukan dari hasil kinerja yang dilakukan.

Kinerja dari institusi dipengaruhi oleh bagaimana tata kelola terhadap usahanya atau yang lebih dikenal dengan Good Corporate Governance (GCG). Pada institusi syariah GCG lebih dikenal dengan istilah Islamic Corporate Governance, dimana ada dua aspek dalam pelaksanaannya. Pertama adalah kepatuhan terhadap hukum Islam dimana setiap pelaksanaan bisnis harus disesuaikan dengan etika dan prinsipprinsip Islam, yang kedua adalah bagaimana perusahaan dapat menyediakan satu set kelengkapan organisasi, pastinya yang sesuai dengan prinsip ekonomi dan keuangan Islam yang berdampak langsung pada kebijakan dan pelaksanaan organisasi, seperti dilarangya konsep riba dalam pelaksaan bisnis, penyaluran dana zakat serta penyelenggaraaan kegiatan bisnis yang mengusung prinsip bagi hasil sesuai dengan prinsip ekonomi Islam (Lewis, 2005).

Lemah nya tata kelola perusahaan dapat mempengaruhi kinerja institusi tidak terkecuali pada institusi syariah, seperti yang dikutip dari Grais dan Pellegrani 2006 pada Asrori 2014 yang menunjukan suatu fenomena dimana terjadi kebangkrutan pada lembaga keuangan Islam, yaitu mulai dari bangkrutnya Bank Islam Afrika Selatan di tahun 1997, kasus runtuhnya lembaga syariah terbesar di Turki yaitu "Ihlas Finance House" pada tahun 2001, serta penipuan yang berujung kebangkrutan di Dubai Islamic Bank antara tahun 2004 sampai dengan 2007. Kejadian-kejadian tersebut diduga terjadi karena kegagalan mekanisme internal dan eksternal tata kelola perusahaan. Dimana kelemahan tata kelola perusahaan syariah dapat terjadi karena 2 hal utama yaitu terkait syariah compliance, yaitu tidak adanya jaminan institusi syariah sudah menyelenggarakan praktik bisnisnya secara keseluruhan dengan mematuhi prinsip-prinsip syariah. Disamping itu tidak adanya jaminan keamanan bagi dana-dana milik deposan dari risikorisiko finansial (Volker, 2003). Kondisi ini menjadi indikator dibutuhkannya serta 
pentingnya tata kelola perusahaan yang sehat pada lembaga perbankan Islam.

Berkaitan dengan kinerja, (Asrori, 2014) mengukur implementasi Islamic corporate governance terhadap kinerja bank syariah dilihat dari kinerja yang berkaitan dengan prinsip syariah yaitu kinerja yang diukur dengan rasio keuangan syariah conformity pembiayaan bagi hasil, pendapatan Islam dan zakat. Pelaksanaan tugas dan tanggung jawab dewan pengawas syariah (DPS) dijadikan sebagai indikator Islamic Corporate Governance ditambah dengan penghimpunan dan penyaluran dana menunjukan pengaruh positif terhadap kinerja bank syariah yang diukur menggunakan rasio-rasio keuangan syariah conformity.

Dalam penelitian ini indikator yang digunakan dalam mengukur Islamic Corporate Governance adalah peran dan tanggung jawab dewan pengawas syariah, sebagai suatu badan yang "unik" merupakan mekanisme internal yang ada dalam lembaga Islam. Bertugas untuk memastikan dengan bekerja sama dengan mekanisme internal lain seperti dewan direksi sebagai pemilik kekuasaan eksekutif tertinggi dari perusahaan, managemen, serta audit internal bahwa semua aktivitas perusahaan sejalan dengan hukum-hukum Islam (Larbsh, Mansor M, 2015). Dimana indikator yang digunakan adalah jumlah pertemuan yang dilakukan (rapat) oleh DPS serta rapat audit Internal dalam satu tahun. Ditambah dengan rasio independent directors dibandingkan dengan jumlah direksi yang ada dalam perusahaan.

Penggunaan indikator Islamic Performance Index merupakan alat pengukuran kinerja yang dapat menunjukan nilai materialitas serta nilai spiritual dari bank Islam. Banyak studi yang dilakukan sebelumnya hanya mengukur tentang kinerja keuangan, dimana hal ini tidak sesuai dengan tujuan utama dari perbankan Islam. Oleh karena itu dalam penelitian ini, peneliti berkeinginan untuk mengukur kinerja dari perbankan syariah tanpa meninggalkan nilai-nilai utama yang mendasari praktek perbankan syariah sendiri yaitu nilai-nilai Islam. Beberapa penelitian yang pernah dilakukan dalam mengukur kinerja berdasarkan Islamic Performance masih berupa studi perbandingan antara dua bank seperti halnya yang dilakukan oleh Aisjah dan Hadianto 2012 yang menyatakan bahwa Bank Muamalat dan BSM Indonesia tahun 2009-2010 menunjukan bahwa kinerja kedua bank tersebut berdasarkan prinsip Islam cukup memuaskan, namun pada rasio zakat dan rasio kesejahteraan direksi dan karyawan masih belum memuaskan. Secara umum kinerja bank Islam Indonesia yang didasarkan pada indeks kinerja Islam menunjukan masih adanya beberapa rasio yang masih mendapatkan predikat belum memuaskan pada pengelolaannya, dilihat dari rendahnya nilai score berdasarkan hasil assessment atas data annual report perbankan syariah yang telah dipublikasikan. 
Permasalahan yang terjadi terkait kinerja keuangan pada perbankan syariah tidak hanya berkaitan dengan permasalahan pencapaian target keuangan seperti yang telah ditetapkan sebelumnya. Lebih penting dari hal tersebut adalah peran lembaga keuangan syariah sendiri yang mempunyai tujuan tidak hanya finansial, namun juga fungsi sosial yang dalam hal ini tercermin dari setiap kegiatannya yang seharusnya berlandaskan kepatuhan terhadap prinsipprinsip syariah.

Selanjutnya dari permasalahan di atas, perumusan masalah sebagai berikut: apakah jumlah pertemuan (rapat) dewan pengawas syariah berpengaruh terhadap kinerja yang berdasarkan pada Islamic Performance Index, apakah independent directors berpengaruh terhadap kinerja yang berdasarkan pada Islamic Performance Index, apakah jumlah pertemuan komite audit berpengaruh terhadap kinerja yang berdasarkan pada Islamic Performance Index?

\section{KERANGKA TEORITIS DAN HIPOTESIS}

Sharia Enterprise Theory merupakan suatu konsep teori yang menjelaskan bahwa tanggung jawab perusahaan tidak hanya terhadap para pemilik perusahaan melainkan terhadap keseluruhan stakeholder yang berkaitan dengan perusahaan. Para pemangku kepentingan menurut pandangan SET meliputi Alloh, manusia dan alam. Peranan teori ini pada kegiatan perbankan syariah diharapkan dapat membuat kinerja bank lebih baik, perilaku manajemen akan lebih termotivasi untuk mematuhi prinsipprinsip yang telah ditetapkan sebagaimana tanggung jawabnya terhadap keseluruhan stakeholder. Semakin tinggi tingkat kepatuhan syariah dan penerapan Islamic corporate governance dalam menerapkan prinsip tersebut memungkinkan bank untuk mendapatkan katagori sebagai bank sehat. Bank umum syariah juga akan lebih mawas diri dan bijak dalam melaksanakan tugasnya sehingga dapat meminimalisir tindak kecurangan yang mungkin dilakukan. Penerapan prinsip syariah enterprise theory bank umum syariah harus memberikan informasi yang akurat dan transparan, sehingga pemilik modal yakin terhadap kebenaran informasi laporan keuangan yang di terbitkan oleh pihak bank umum syariah.

Berkaitan dengan perbedaan kepentingan dari para stakeholders, muncul Agency theory yang menurut oleh Jensen dan Meckling (1976) memandang bahwa manajemen perusahaan sebagai agen bagi para pemegang saham, akan bertindak dengan penuh kesadaran bagi kepentingannya sendiri, bukan sebagai pihak yang bijaksana serta adil terhadap pemegang saham. Dapat dikatakan pula bahwa management punya indikasi untuk bertindak demi keuntungan mereka sendiri bukan untuk kepentingan organisasi maupun keseluruhan stakeholder pada umumnya dan shareholder khususnya, kondisi tersebut yang menimbulkan munculnya masalah keagenan. Terkait dengan hal tersebut 
mekanisme corporate governance perlu dilakukan sebaik-baiknya untuk mencegah berkembangnya konflik keagenan tersebut.

Didukung dengan teori legitimasi, yang dinilai sesuai dengan perbankan syariah, dimana setiap aktivitas yang dilakukan sesuai dengan fungsinya sebagai lembaga keuangan bank yang merupakan bagian dari struktur perbankan nasional, akan tetapi terdapat nilai- nilai khusus yang dijadikan sebagai pedoman yaitu nilai Islami. Keberadaan prinsip syariah yang harus dipatuhi, serta adanya lembaga pengawasan terkait dalam hal ini tugas dan tanggungjawab dewan pengawas syariah berkaitan dengan teori legitimasi ini. Dimana peranan DPS dalam perbankan syariah yaitu memastikan semua aktivitas institusi sudah diselaraskan dan sesuai dengan prinsip-prinsip Islam.

Berkaitan dengan agency theory Dewan Pengawas Syariah dapat dijadikan sebagai pihak yang memastikan bank sebagai management dapat dipercaya untuk mengelola organisasi termasuk menjaga asset perusahaan dan bertindak untuk kepentingan seluruh stakeholder, bukan hanya berorientasi pada kepentingan pribadi. Sejalan dengan hasil Penelitian yang dilakukan oleh Asrori (2014) yang menunjukkan hubungan positif antara implementasi Islamic corporate governance pelaksanaan tugas dan tanggung jawab Dewan Pengawas Syariah dengan kinerja bank. Berdasarkan uraian di atas, hipotesis yang diajukan adalah :

H1 : Jumlah rapat DPS berpengaruh terhadap kinerja syariah BUS dengan menggunakan indikator profit sharing ratio.

H2 : Jumlah rapat DPS berpengaruh terhadap kinerja syariah BUS dengan menggunakan indikator Islamic income ratio.

H3 : Jumlah rapat DPS berpengaruh terhadap kinerja syariah BUS dengan menggunakan indikator equitable distribution ratio.

Implikasi dari teori legitimasi pada penelitian ini adalah eksistensi Dewan Direksi/Direktur, dimana direksi menjalankan tugas dan tanggung jawabnya sesuai dengan prinsip syariah. Direksi dapat dipercaya untuk bertindak dengan sebaik-baiknya bagi kepentingan publik maupun stakeholder sehingga disinilah kepercayaan terhadap perbankan syariah dapat ditumbuhkan. Selain itu, pihak direksi seharusnya dapat menjalankan perannya dengan baik dalam setiap keputusan maupun kebijakan yang dikeluarkan sebagai wakil dari management, untuk mencegah adanya konflik kepentingan antara shareholder sebagai principal dengan managemen sebagai agen. Untuk dapat memberikan kepercayaan dan keyakinan kepada stakeholder nya, dewan direksi perlu disusun dalam suatu komposisi yang tepat. Dimana komposisi tepat yang dimaksud adalah jumlah yang memadai atas direksi yang independen (non kepentingan), sehingga mereka dapat berlaku objektif terhadap kinerja 
terbaik perusahaan. Berdasarkan hal tersebut, hipotesis yang diajukan adalah :

$\mathrm{H} 4$ : Independent directors berpengaruh terhadap kinerja syariah BUS dengan menggunakan indikator profit sharing ratio.

H5 : Independent directors berpengaruh terhadap kinerja syariah BUS dengan menggunakan indikator Islamic Income ratio.

H6 :Independent directors berpengaruh terhadap kinerja syariah BUS dengan menggunakan indikator equitable distribution ratio.

Peran dan tanggung jawab dari komite audit tidak jauh berbeda dengan DPS, yang membedakan adalah komite audit lebih berkonsentrasi pada memastikan setiap aktivitas baik operasional maupun bisnis perusahaan sudah dijalankan sesuai dengan aturan dan prosedur yang ada. Hal ini sesuai dengan implikasi dari teori legitimasi. Sesuai dari tugas utama komite audit bekerja untuk mencegah kemungkinan kerugian, penyimpangan dan tidak tercapainya tujuan dari perusahaan. Rapat komite audit menunjukan suatu kebutuhan adanya pembahasan terkait kinerja baik operasional maupun bisnis bank,dalam hal memastikan semua kinerja sudah sesuai dan taat terhadap sistem, kebijakan dan prosedur yang ada.

H7 : Jumlah rapat komite audit berpengaruh terhadap kinerja syariah BUS dengan menggunakan indikator profit sharing ratio.

H8 : Jumlah rapat komite audit berpengaruh terhadap kinerja syariah BUS dengan menggunakan indikator Islamic Income ratio.

H9 : Jumlah rapat komite audit berpengaruh terhadap kinerja syariah BUS dengan menggunakan indikator equitable distribution ratio.

\section{METODOLOGI}

Penelitian ini dilakukan terhadap bank umum syariah di Indonesia, sedangkan penarikan sampel dilakukan dengan menggunakan metode purposive sampling. Pengumpulan data dengan cara dokumentasi dari annual report dan laporan self assessment dari laporan good corporate governance yang diterbitkan oleh bank syariah yang memenuhi kriteria. Berdasarkan kriteria yang ditetapkan terdapat 9 BUS yang digunakan sebagai sampel penelitian, dengan periode pengamatan dilakukan untuk periode 2012 sampai dengan 2016.

Metode analisis yang digunakan adalah dengan menggunakan analisis regresi linear berganda, dimana sebelumnya dilakukan uji asumsi klasik meliputi: uji normalitas, heterokedastisitas, multikolinearitas dan otokorelasi.

\section{HASIL DAN PEMBAHASAN}

Berdasarkan hasil analisis untuk uji pengaruh, ditunjukan nilai $R$ square terhadap hubungan variabel yang pertama sebesar 0.024. Hal ini berarti bahwa variasi kinerja syariah dengan menggunakan indikator profit sharing ratio dapat dijelaskan oleh variasi rapat 
DPS, independent directors dan jumlah rapat komite audit sebesar $2,4 \%$. Nilai $R$ square terhadap hubungan variabel yang pertama sebesar 0.138. Hal ini berarti bahwa variasi kinerja syariah dengan menggunakan indikator Islamic Income ratio dapat dijelaskan oleh variasi rapat DPS, independent directors dan jumlah rapat komite audit sebesar 13,8\%. Sedangkan, nilai adjusted $R$ square terhadap hubungan variabel dependen EDR adalah sebesar 0.020. Hal ini berarti bahwa variasi variasi kinerja syariah dengan menggunakan indikator Equitable Distribution ratio dapat dijelaskan variasi rapat DPS, independent directors dan jumlah rapat komite audit sebesar 2,0\%.

Nilai $F$ hitung variabel profit sharing ratio adalah sebesar 0,338 sedangkan nilai $\mathrm{F}$ tabel nya adalah 2,833 sehingga $\mathrm{F}$ hitung $(0,338)<$ nilai $\mathrm{F}$ tabel (2,833). Sedangkan nilai nilai signifikansi dari $\mathrm{F}$ adalah 0,798 yang melebihi nilai $\alpha$ nya yaitu 0,05 . Sehingga dapat disimpulkan bahwa variabel bebas secara simultan yang dalam hal ini adalah variabel rapat DPS, independent directors dan jumlah rapat komite audit tidak mampu menjelaskan perubahan pada variabel dependen, dan persamaan regresi atau model tidak masuk kriteria kecocokan.

Nilai F hitung variabel Islamic Income ratio adalah sebesar 2,188 sedangkan nilai $\mathrm{F}$ tabel nya adalah 2,833 sehingga $\mathrm{F}$ hitung $(2,188)<$ nilai $\mathrm{F}$ tabel (2,833). Sedangkan nilai nilai signifikansi dari $\mathrm{F}$ adalah 0,104 yang melebihi nilai $\alpha$ nya yaitu 0,05 . Sehingga dapat disimpulkan bahwa variabel bebas secara simultan yang dalam hal ini adalah variabel rapat DPS, independent directors dan jumlah rapat komite audit tidak mampu menjelaskan perubahan pada variabel dependen Islamic Income ratio, dan persamaan regresi atau model tidak masuk kriteria kecocokan.

Nilai F hitung variabel Islamic Income ratio adalah sebesar 0,276 sedangkan nilai $\mathrm{F}$ tabel nya adalah 2,833 sehingga $F$ hitung $(0,276)<$ nilai $F$ tabel $(2,833)$. Sedangkan nilai signifikansi dari $F$ adalah 0,842 yang melebihi nilai $\alpha$ nya yaitu 0,05 . Sehingga dapat disimpulkan bahwa variabel bebas secara simultan yang dalam hal ini adalah variabel rapat DPS, independent directors dan jumlah rapat komite audit tidak mampu menjelaskan perubahan pada variabel dependen equitable distribution ratio, dan persamaan regresi atau model tidak masuk kriteria kecocokan.

Hipotesis yang berkaitan dengan variabel rapat DPS sebagai variabel bebas. Hipotesis pertama mendapatkan output, nilai t hitung sebesar $-0,407>$ dari nilai $\mathrm{t}$ tabel $-2,020$. Selain itu nilai signifikansi $0,686>$ nilai signifikansi $(\alpha=0,05)$ yang artinya variabel rapat DPS tidak berpengaruh signifikan terhadap variabel kinerja syariah dengan menggunakan indikator profit sharing ratio dan pengaruh yang diberikan adalah negatif. Hipotesis kedua mendapatkan output, nilai t hitung sebesar 2,229 > dari nilai $\mathrm{t}$ tabel 2,020. Selain itu nilai signifikansi $0,031<$ nilai signifikansi 
$(\alpha=0,05)$ yang artinya variabel rapat DPS berpengaruh signifikan terhadap variabel kinerja syariah dengan menggunakan indikator Islamic Income ratio dan pengaruh yang diberikan adalah positif. Hipotesis ketiga mendapatkan output, nilai $t$ hitung sebesar $-0,315>$ dari nilai $t$ tabel -2,020. Selain itu nilai signifikansi $0,754>$ nilai signifikansi $(\alpha=0,05)$ yang artinya variabel rapat DPS tidak berpengaruh signifikan terhadap variabel kinerja syariah dengan menggunakan indikator Equitable Distribution ratio dan pengaruh yang diberikan adalah negatif.

Hipotesis keempat yang berkaitan dengan variabel independens directors menunjukan nilai t hitung $-0,844$, > dari nilai $\mathrm{t}$ tabel $-2,020$. Selain itu nilai signifikansi $0,754>$ nilai signifikansi $(\alpha=0,05) \quad$ yang artinya variabel independent directors tidak berpengaruh signifikan terhadap variabel kinerja syariah dengan menggunakan indikator IIR dan pengaruh yang diberikan adalah negatif. Hipotesis kelima menunjukan output $-0,174>$ dari nilai t tabel $-2,020$. Selain itu nilai signifikansi $0,247>$ nilai signifikansi $(\alpha=0,05)$ yang artinya variabel independent directors tidak berpengaruh signifikan terhadap variabel kinerja syariah dengan menggunakan indikator IIR dan pengaruh yang diberikan adalah negatif.

Hipotesis keenam output yang dihasilkan adalah $0,856<$ nilai $\mathrm{t}$ table 2,020, selain itu nilai signifikansi 0,397> nilai signifikansi $(\alpha=0,05)$ yang artinya variabel independent directors tidak berpengaruh signifikan terhadap variabel kinerja syariah dengan menggunakan indikator EDR dan pengaruh yang diberikan adalah positif.

Hipotesis ketujuh berkaitan dengan pengaruh variabel rapat komite audit, output yang dihasilkan adalah $0,188<$ nilai $\mathrm{t}$ table 2,020, selain itu nilai signifikansi $0,852>$ nilai signifikansi $(\alpha=0,05)$ yang artinya variabel jumlah rapat komite audit tidak berpengaruh signifikan terhadap variabel kinerja syariah dengan menggunakan indikator EDR dan pengaruh yang diberikan adalah positif. Hipotesis kedelapan berkaitan dengan pengaruh variabel rapat komite audit, output yang dihasilkan adalah $0,792<$ nilai t table 2,020, selain itu nilai signifikansi $0,433>$ nilai signifikansi $(\alpha=0,05)$ yang artinya variabel jumlah rapat komite audit tidak berpengaruh signifikan terhadap variabel kinerja syariah dengan menggunakan indikator EDR dan pengaruh yang diberikan adalah positif. Hipotesis kesembilan berkaitan dengan pengaruh variabel rapat komite audit, output yang dihasilkan adalah $0,314>$ nilai t table $-2,020$, selain itu nilai signifikansi $0,755>$ nilai signifikansi $(\alpha=0,05)$ yang artinya variabel jumlah rapat komite audit tidak berpengaruh signifikan terhadap variabel kinerja syariah dengan menggunakan indikator EDR dan pengaruh yang diberikan adalah positif. Berdasarkan hasil analisis data, Persamaan model dalam penelitian ini adalah sebagai berikut:

$\mathrm{Y} 1=0,606-0,002 \mathrm{X}_{1}$

$0,210 \mathrm{X}_{2}+0,001 \mathrm{X} 3+\mathrm{e}$ 
$\mathrm{Y} 1=0,867+0,008 \mathrm{X}_{1}-0,183 \mathrm{X}_{2}$ $+0,002 \mathrm{X} 3+\mathrm{e}$

$\mathrm{Y} 1=0,204-0,001 \mathrm{X}_{1}+0,135 \mathrm{X}_{2}-0,001 \mathrm{X} 3$ $+\mathrm{e}$

1. Hipotesis Jumlah rapat Dewan Pengawas Syariah berpengaruh signifikan terhadap kinerja bank syariah dengan menggunakan indikator profit sharing ratio, Islamic Income ratio, dan Equitable Distribution ratio.

Berdasarkan hasil pengujian statistik terhadap data menunjukan bahwa jumlah rapat DPS tidak mempunyai pengaruh yang signifikan terhadap kinerja terkait pembiayaan berbasis bagi hasil dan kinerja bank dalam mendistribusikan pendapatan yang wajar, serta pengaruhnya adalah negatif. Hal ini berarti setiap peningkatan terhadap jumlah rapat DPS akan berdampak negatif terhadap kinerja syariah dalam mengelola bagi hasil maupun dalam mendistribusikan pendapatan meskipun pengaruhnya kecil. Dapat disimpulkan juga bahwa peningkatan dalam volume rapat DPS akan mengakibatkan penurunan terhadap kemampuan bank syariah dalam mengelola bagi hasil dan mendistrisibusikan pendapatan.

Peran yang dilakukan DPS dalam melakukan pengawasan terhadap aktivitas pengelolaan pembiayaan berbasis bagi hasil adalah bahwa DPS harus memastikan bank tidak hanya berkonsentrasi dalam memaksimalkan keuntungan (margin) melainkan harus bisa memberikan manfaat yang lebih terhadap masyarakat dengan menyalurkan pembiayaan berbasis bagi hasil. Jumlah rapat DPS berpengaruh negatif terhadap kinerja syariah bank dalam hal ini, dimungkinkan terjadi karena peningkatan pengelolaan pembiayaan bagi hasil tidak hanya terukur dari berapa banyak jumlah rapat yang diadakan oleh DPS. Kepentingan DPS adalah terkait seluruh aktivitas operasional dan bisnis bank, sehingga setiap pertemuan yang diagendakan membahas hal yang sangat kompleks tanpa terpaku pada aktivitas tertentu. Peran DPS lebih kepada bagaimana DPS bisa memberikan pembinaan dan motivasi yang membuat managemen selalu bekerja dengan fokus pada memberikan manfaat yang luas terhadap para stakeholders. Sehingga aktivitas bank tidak lagi hanya didominasi oleh aktivitas-aktivitas dengan prinsip jual beli seperti murabahah. Karena prinsip bagi hasil sendiri merupakan kekhasan dari sistem perbankan Islam sehingga porsinya seharusnya paling besar dibandingkan dengan jenis pembiayaan lain, dengan tujuan untuk memberikan manfaat yang maksimal terhadap masyarakat.

Hal yang sama ditujukan terhadap kinerja bank dalam penyaluran serta menerapkan dengan tepat pendistribusian pendapatan yang diterima BUS terhadap setiap stakeholder nya yang direpresentasikan dengan jumlah yang disalurkan untuk dana Qardh dan sosial, biaya tenaga kerja, laba operasi perusahaan dibandingkan dengan total pendapatan yang diterima dikurangi zakat dan pajak. 
Hasil yang berbeda ditunjukan dari pengaruh peran DPS terhadap kinerja dalam mengelola pendapatan Islam. Dimana jumlah rapat DPS berpengaruh positif terhadap kinerja dengan menggunakan indikator rasio pendapatan Islam. Dalam hal bagaimana bank meningkatkan rasio pendapatan Islami yaitu memaksimalkan jumlah pendapatan halal bank, peran DPS juga memastikan kinerja mereka dalam menghasilkan pendapatan sudah sesuai dengan prinsip syariah, sehingga dapat mengurangi jumlah pendapatan non halal bank.

Hasil ini sesuai dengan teori legitimasi terkait eksistensi Dewan Pengawas Syariah, dimana Dewan Pengawas Syariah menjalankan tugas dan tanggung jawabnya dengan berpedoman pada prinsip syariah yang harus dijalankan pada setiap aktivitas yang dijalankan bank syariah. Pertemuan yang dilakukan oleh DPS dapat dijadikan sebagai indikator kinerja DPS, dimana dalam setiap rapat yang diadakan DPS yang merupakan wakil dari masyarakat terutama terkait dengan faktor religiousity untuk dapat memastikan pengelolaan bank sudah dijalankan sesuai dengan prinsip syariah, sehingga setiap dana, transaksi serta fasilitas yang dimanfaatkan oleh masyarakat dapat dipastikan kehalalannya. Pengelolaan terhadap pembiayaan berbasis bagi hasil harus diawasi dengan baik oleh DPS dan apabila dinilai ada hal-hal yang perlu dilakukan pembenahan terhadap kinerja BUS dalam penyaluran dana perlu dilakukan pertemuan antar DPS untuk kemudian disampaikan kepada managemen perusahaan.

2. Hipotesis berkaitan dengan pengaruh independen directors terhadap kinerja bank syariah dengan menggunakan indikator profit sharing ratio, Islamic Income ratio, dan Equitable Distribution ratio

Komposisi independent directors memiliki pengaruh negatif namun tidak signifikan terhadap kinerja berdasarkan kinerja dalam hal penyaluran pembiayaan berbasis bagi hasil dan kinerja dalam pengelolaan pendapatan Islam. Menunjukan bahwa peningkatan jumlah direktur independen yang ada dalam BUS dapat berdampak pada penurunan kinerja bank dalam menghasilkan mengelola pembiayaan bagi hasil dan pendapatan Islami, meskipun pengaruhnya tidak signifikan. Hal ini memungkinkan terjadi, diakibatkan fokus dari direksi adalah dalam pencapaian target yang biasanya terukur dari target keuangan yang tinggi, sehingga direksi cenderung tertarik untuk peningkatan volume pendapatan dan kadang mengindahkan aturan atau bahkan tidak mementingkan pendapatan yang diperoleh dari transaksi halal maupun non halal (sebagai contoh : direksi menyetujui investasi pada instrument keuangan yang diterbitkan perusahaan konvensional diakibakan mereka melihat tingkat return yang dihasilkan maksimal) kinerja syariah BUS dengan menggunakan indikator Islamic income ratio. Begitu juga dengan pembiayaan berbasil bagi hasil yang 
dinilai mempunyai tingkat resiko yang tinggi untuk bank, sehingga dimungkinkan direksi cenderung memilih pembiayaan yang menghasilkan margin yang jelas dibandingkan dengan menyalurkan pembiayaan berbasis bagi hasil.

Independent directors memiliki pengaruh positif namun tidak signifikan terhadap kinerja syariah bank dengan menggunakan indeks EDR, yang berarti setiap peningkatan jumlah direktur independen dapat berpengaruh dalam meningkatkan kinerja managemen dalam melakukan distribusi pendapatan terhadap stakeholder dan untuk kepentingankepentingan lainnya. Hal ini mungkin terjadi, direksi dalam hal ini independen direktur yang tidak mempunyai kepentingan khusus (karena tidak memiliki kepemilikan saham) mempunyai target atas pencapaian kinerja keuangan yang maksimal untuk menunjukan performance nya. Sehingga mereka harus membuat kebijakan terkait dengan pengeloaan dana dan pendistribusian yang tepat atas pendapatan, agar kinerja keuangan selalu dapat terjaga dengan baik.

3. Hipotesis berkaitan dengan pengaruh jumlah rapat komite audit terhadap kinerja bank syariah dengan menggunakan indikator profit sharing ratio, Islamic Income ratio, dan Equitable Distribution ratio

Komite audit internal perusahaan mempunyai tugas untuk memastikan aktivitas organisasi berjalan sesuai dengan sistem, aturan dan prosedur yang sudah dibuat. Tujuan utamanya adalah pengamanan asset perusahaan dan mencegah adanya aktivitas moral hazard dari managemen untuk menghindari kerugian perusahaan. Hasil penelitian menunjukan pengaruh positif rapat komite audit terhadap kinerja syariah yang dihasilkan oleh organisasi pada kegiatan penyaluran pembiayaan berbasis bagi hasil dan kinerja dalam mengelola pendapatan Islam. Menunjukan bahwa dengan adanya rapat komite audit dapat berperan dalam peningkatan kinerja bank dalam mengelola pembiayaan berbasis bagi hasil dan pengelolaan terhadap pendapatan Islam, meskipun pengaruhnya kecil. Karena merupakan produk andalan, komite audit harus memberikan pengawasan dan supervisi yang maksimal dalam hal ini ditunjukan dengan semakin banyak jumlah pertemuan diantara komite audit untuk memastikan bahwa kinerja managemen dalam penyaluran pembiayaan bagi hasil sudah benar dan sesuai dengan sistem dan prosedur yang ditetapkan bank. Peningkatan jumlah pertemuan akan mengindikasikan kinerja komite audit meningkat dalam melakukan pengawasan maupun supervisi.

Begitu juga dalam pengelolaan terhadap pendapatan Islam. Komite audit dalam hal ini melakukan pengawasan dan supervisi bahwa setiap aktivitas yang berkaitan dengan kinerja dalam menghasilkan pendapatan tidak melanggar aturan maupun prosedur yang ada, serta memastikan tidak adanya 
penyimpangan yang dilakukan untuk memanipulasi pendapatan oleh pihakpihak yang mempunyai kepentingan khusus. Semakin banyak jumlah rapat yang diadakan oleh komite audit mengindikasikan perlunya pembenahan terhadap aktivitas organisasi untuk memastikan bank dijalankan dalam kondisi yang baik. Hal ini sesuai dengan implikasi agency theory, dimana adanya komite audit dan semakin banyak jumlah pertemuan yang dilakukan dapat menghindari atau mengurangi asimetri informasi antar stakeholder yang memiliki kepentingan yang berbeda-beda terhadap pengelolaan bank syariah.

Hal yang berbeda berlaku terhadap pengaruh jumlah rapat komite audit pada kinerja bank syariah dalam mendistribusikan pendapatannya. Pengaruh negatif ditunjukan dari peran rapat komite audit terhadap kinerja pendistribusian pendapatan. Yang berarti semakin banyak jumlah rapat komite audit dapat berpengaruh dalam menurunkan kinerja bank dalam pendistribusian pendapatan. Hal ini dimungkinkan terjadi, karena focus dari komite audit dalam hal ini setiap pertemuan yang mereka lakukan adalah membahas aktivitas yang mungkin berdampak pada kerugian bank, sehingga penyaluran pendapatan yang tepat tidak menjadi konsentrasi dari pihak komite audit.

\section{SIMPULAN DAN IMPLIKASI PENELITIAN}

\section{Simpulan}

1. Jumlah rapat Dewan pengawas syariah tidak mempunyai pengaruh yang siginifikan terhadap kinerja terkait pembiayaan berbasis bagi hasil dan kinerja bank dalam mendistribusikan pendapatan yang wajar, serta pengaruhnya adalah negatif. Hal ini berarti setiap peningkatan terhadap jumlah rapat DPS akan berdampak terhadap penurunan kinerja syariah bank dalam mengelola bagi hasil maupun dalam mendistribusikan pendapatan meskipun pengaruhnya kecil. Sedangkan jumlah rapat DPS berpengaruh positif terhadap kinerja dengan menggunakan indikator rasio pendapatan Islam, artinya setiap peningkatan jumlah rapat DPS akan meningkatkan kinerja dalam menghasilkan pendapatan Islami.

2. Komposisi independent directors memiliki pengaruh negatif namun tidak signifikan terhadap kinerja berdasarkan kinerja dalam hal penyaluran pembiayaan berbasis bagi hasil dan kinerja dalam pengelolaan pendapatan Islam. Menunjukan bahwa peningkatan jumlah direktur independen yang ada dalam BUS dapat berdampak pada penurunan kinerja bank dalam mengelola pembiayaan bagi hasil dan pendapatan Islami, meskipun pengaruhnya tidak signifikan. Independent directors memiliki pengaruh positif namun tidak signifikan terhadap kinerja syariah 
bank dengan menggunakan indeks EDR, yang berarti setiap peningkatan jumlah direktur independen dapat berpengaruh dalam meningkatkan kinerja managemen dalam melakukan distribusi pendapatan terhadap stakeholder dan untuk kepentingan-kepentingan lainnya.

3. Jumlah rapat komite audit berpengaruh positif terhadap kinerja syariah yang dihasilkan oleh organisasi pada kegiatan penyaluran pembiayaan berbasis bagi hasil dan kinerja dalam mengelola pendapatan Islam. Menunjukan bahwa dengan adanya rapat komite audit dapat berperan dalam peningkatan kinerja bank dalam mengelola pembiayaan berbasis bagi hasil dan pengelolaan terhadap pendapatan Islam, meskipun pengaruhnya kecil. Pengaruh negatif ditunjukan dari peran rapat komite audit terhadap kinerja pendistribusian pendapatan. Yang berarti semakin banyak jumlah rapat komite audit dapat berpengaruh dalam menurunkan kinerja bank dalam pendistribusian pendapatan.

\section{Implikasi Penelitian}

Penelitian ini dapat memberikan masukan bagi bank syariah pada khususnya serta perekonomian Islam di Indonesia. Sesuai dengan implikasi dari Syariah Enterprises Theory bahwa setiap aktivitas usaha tidak hanya ditujukan terhadap stakeholder langsung namun juga harus mampu dipertanggungjawabkan kepada Alloh sebagai pemilik tunggal alam semesta. Berdasarkan hal tersebut setiap pengelolaan terhadap aktivitas usaha tidak semata-mata mengejar aspek duniawi, melainkan terhadap aspek syariah yang dalam hal ini dapat diukur dengan menggunakan indikator kinerja berbasis syariah.

\section{DAFTAR PUSTAKA}

Asrori. Implementasi Islamic Corporate Governance dan implikasinya terhadap kinerja bank syariah. Jurnal Dinamika Akuntansi,Vol. 6, No. 1, Maret, 2014, pp.90-102.

Asrori. Pengungkapan Syari'ah Compliance dan Kepatuhan Bank Syariah Terhadap Prinsip Syariah. Jurnal Dinamika Akuntansi,Vol. 3, No. 1, Maret, 2011, pp.1- 7.

Bank Indonesia. 2007. Surat Edaran No. 9/24/DPbS Perihal Sistem Penilaian Tingkat Kesehatan Bank Umum Berdasarkan Prinsip Syariah. Jakarta: Bank Indonesia.

Bank Indonesia. 2007. Peraturan Bank Indonesia No. 9/1/PBI/2007 tentang Sistem Penilaian Tingkat Kesehatan Bank Umum Berdasarkan Prinsip Syariah. Jakarta: Bank Indonesia.

Davis, J. H.; Schoorman, F. D. and Donaldson, L. 1997. Towards a Stewardship Theory of Management. Academy of Management Review, 22(1), pp. 2047.

Dwi Poetry, Zakiyah. (2011). Pengaruh Variabel Makro dan Mikro Terhadap NPL Perbankan 
Konvensionaldan NPF Perbankan Syariah. Alumni Program Studi Ekonomi STEI TAZKIA.

Dendawijaya, Lukman. 2005. Manajemen Perbankan. Bogor: Ghalia Indonesia. Falikhatun. 2012. Bank Syariah Di Indonesia: Ketaatan Pada Prinsip Syariah dan Kesehatan Finansial, volume 1 Nomor 1 Desember. Hal 245-254.

Ghozali, Imam. 2013. Aplikasi Analisis Multivariate dengan Program SPSS. Semarang: BP UNDIP.

Hisamudin, Nur dan Tirta K, M. Yayang. Pengaruh Good Corporate Governance terhadap Kinerja Keuangan Bank Umum Syariah.

Kuppusamy, Mudiarasan., Ali Salma Saleh, and Ananda Samudhram. 2010. Measurement of Islamic Banks Performance using Shari'a Conformity and Profitability Model. International Association for Islamics Economics. Review of Islamic Economics. Vol. 13, No. 2, pp. $35-48$.

Lewis, Mervyn K. 2005. Islamic Corporate Governance. Review of Islamic Economics, Vol.9 No.1.

Peraturan Bank Indonesia Nomor : 6/24/PBI/2004 Tentang Bank Umum yang Melaksanakan Kegiatan Usaha Berdasarkan Prinsip Syariah.

Peraturan Bank Indonesia Nomor : 9/1/PBI/2007 Tentang Sistem Penilaian Tingkat Kesehatan Bank Umum Berdasarkan Prinsip Syariah. Peraturan Bank Indonesia Nomor : 11/ 3
/PBI/2009 Tentang Bank Umum Syariah. Peraturan Bank Indonesia Nomor: 11/33/PBI/2009 tentang Pelaksanaan GCG Bagi BUS dan UUS

Triyanta, Agus. 2009. Implementasi Kepatuhan Syariah dalam Perbankan Islam (Syariah) (Studi Perbandingan antara Malaysia dan Indonesia). Dalam Jurnal Hukum No. Edisi Khusus Vol. Hal. 209228. Yogyakarta: Universitas Islam Indonesia Yogyakarta 